\title{
Criminal Justice and Criminology at the Core: Using a Sustainable Method for Constructing a Core Journal List
}

\author{
Joseph Aubele ${ }^{\mathrm{a}^{*}}$ \\ Gabriel J. Gardner ${ }^{b}$
}

This is an electronic version of an article published as Joseph Aubele \& Gabriel J. Gardner (2021) Criminal Justice and Criminology at the Core: Using a Sustainable Method for Constructing a Core Journal List, The Serials Librarian AHEAD OF PRINT, 1 - 16, doi: 10.1080/0361526X.2021.1986195. Serials Librarian is available online at: https://www.tandfonline.com/loi/wser20

\begin{abstract}
Author Note
${ }^{a}$ University Library, California State University Long Beach, Long Beach, United States of America; ORCID https://orcid.org/0000-0002-6609-0876

${ }^{\mathrm{b}}$ University Library, California State University Long Beach, Long Beach, United States of America; ORCID https://orcid.org/0000-0002-9996-5587

* email: joseph.aubele@,csulb.edu telephone: 562.985 .5321 postal: c/o University Library, California State University Long Beach, 1250 Bellflower Blvd., Long Beach, CA 90840-1901
\end{abstract}




\begin{abstract}
The desire to identify which journals are core to a discipline is important to librarians and departmental faculty alike. Whether for purposes of accreditation, decisions related to retention, tenure, and promotion, or the assessment of a library's collection, core lists are highly valued resources. Applying a previously tested, mixed-methods approach, the authors created a five-tiered list of criminal justice and criminology journals from which 151 titles were identified as being core to the discipline. In an effort to assess the reliability of their results, the authors also compared the results of their study to a list created by criminal justice scholars.
\end{abstract}

Keywords: Core journals; scholarly communication; collection development; academic libraries; academic librarians 


\section{Introduction}

The effort to understand which journals are the "best" or most influential is familiar to many, if not all, disciplines. The inexhaustible need for authoritative lists has been fueled by any number of sources, including departments seeking accreditation, committees evaluating the credentials of candidates for employment or as part of the retention, tenure and promotion process, and, of course, librarians evaluating a collection. Over time, various methods for building such lists have been developed including the opinion(s) of experts, citation analysis, and inclusion in abstracting and indexing services. . Concurrently, there has also been a steady drumbeat of criticism regarding core lists, primarily focusing on how they are constructed and used (e.g., Laband ${ }^{1} \mathrm{Nkomo}^{2}$ Sangster $^{3}$, Tadajewski ${ }^{4}$ ).

Mindful of the criticisms leveled against core lists and journal ranking, the co-authors decided to employ a previously tested, mixed-methods approach to construct a stratified tier journal list for the criminal justice and criminology disciplines. The approach used for this study blends two popular methods for core list construction (i.e., citation analysis and titles indexed by commercial databases) while also including the expertise of the Library of Congress. Each individual method results in a list which, when compared, results in stratified tiers of titles which appear on one, two, or more of the prior lists. By comparing overlap between lists, a robust and clear understanding of what constitutes the core emerges: those titles on a majority of the lists. The effect of this mixedmethod approach is to leverage the strengths of the individual methods while also mitigating their respective weaknesses. Further, the method employed for this study can be used by an individual librarian, thereby allowing for updated core lists to be created with greater frequency. There is an extensive corpus on the topic of core journals and journal rankings in the disciplines of criminal justice and criminology. However, many of the lists include a relatively small number of titles. So, the co-authors (one of whom serves as criminal justice librarian and the other who formerly served in that role) undertook this study to create a list that balances selectivity with a higher degree of inclusivity.

\section{Literature Review}

The use of lists to assess and manage library collections has a long history in libraries in the United States, going back more than a century. ${ }^{5}$ Not surprisingly, several methodologies have been used to pursue core journal lists. Of particular note have been the use of expert rankings (a.k.a. perceptual rankings), the inclusion of journals in abstracting and indexing services (A \& I), and reliance on citation analyses of works published in journals. A brief discussion of these methods and their respective strengths and weaknesses is important to understand the reasons for using a mixed-method approach for this study.

As observed by Nisonger, reliance upon the judgment of those presumed to be experts in their field is one of the oldest methods for identifying core journals. ${ }^{6}$ Examples of this approach are plentiful and can be found in disparate areas of scholarship, from business ${ }^{7}$, finance ${ }^{8}$, nonprofit and civil society studies ${ }^{9}$, and social work. ${ }^{10}$ Within the discipline of criminal justice, early examples of the importance of perceptual rankings to the discipline can be found in the work of David Fabianic, both in $1980^{11}$ and again in $1981^{12}$, that included a survey of the membership of the Academy of Criminal Justice Sciences as part of an effort to determine the leading journals in the field. Subsequent studies by other scholars which also incorporated survey methodology have appeared 
irregularly since (e.g., Green, et al. ${ }^{13}$, Sorensen, et al. ${ }^{14}$, Williams III, et al. ${ }^{15}$ ). However, besides being labor-intensive, critics have found that these perceptual ratings sometimes measure something other than the perceived reputation of journals ${ }^{16}$ or are built upon "a set of untenable assumptions." ${ }^{17}$ Further, as with any subjective measure, the potential bias of survey respondents is a cause for concern (e.g., Serenko and Bontis ${ }^{18}$, Walters ${ }^{19}$ ).

Another approach to identifying the core journals within a discipline that has enjoyed regular use (e.g., Bobrinkski ${ }^{20}$, Paynter, et al. ${ }^{21}$, Peritz ${ }^{22}$, Serebnick and Harter $^{23}$ ), though of limited popularity within the field of criminology or criminal justice ${ }^{24}$, has been relying upon the judgment of abstracting \& indexing (A\&I) services. Some proponents have argued that a journal's inclusion in a popular index underscores the importance of the publication while also increasing the title's visibility and likely use. ${ }^{25}$ For librarians the collective wisdom of A\&I services implies credibility. ${ }^{26}$ Despite these considerations, criticism of this method includes the observation that, consistent with the so-called " $80 / 20$ rule," the majority of usage comes from a relatively small subset of titles (i.e., only a fraction of the "core" journals are used) ${ }^{27}$ and that there is often a lack of transparency in the selection criteria for inclusion in an A\&I service. ${ }^{28}$ Related to that, it is sometimes unclear whether a journal title is indexed because it is core to a discipline or core to a discipline because it is indexed. ${ }^{29}$ Reinforcing this argument is a recent study that found that 1,601 Library \& Information periodicals were indexed across four electronic A\&I services (i.e., databases),$^{30}$ which begs the question which of these are core to that discipline? Ultimately, while hundreds of journals might be useful, some are more important than others.

The final method for consideration here, and perhaps the most popular, is citation analysis. In 1927 an evaluation of citations contained in a single volume year of a journal was undertaken. ${ }^{31}$ Since then, tens of thousands of citation analyses have been undertaken (a recent Google Scholar search for the term "citation analysis" yielded more than 94,000 results) across nearly every scholarly discipline imaginable. The reasons for the popularity of this approach include "the assumption that [a] citation is ... an indication of quality" 32 and "that citation counts are strongly correlated with ... scholarly prestige." ${ }^{33}$ In the disciplines of criminal justice and criminology, this method has been used frequently to assess the productivity of scholars and programs (e.g., Ahlin $^{34}$ Cohn and Farrington ${ }^{35}$, Sorensen ${ }^{36}$ ). But for scholars, either individually or as part of a group of researchers, the work necessary to undertake such an analysis can be daunting. For example, the Excellence in Research for Australia project employed 700 experts to create a journal ranking. ${ }^{37}$ Meanwhile, the Gross and Gross analysis identified more than 3,600 references from 247 journals ${ }^{38}$, and by the late $20^{\text {th }}$ century and into the $21^{\text {st }}$ century, it has not been unusual for researchers to consider upwards of 20,000 articles for a single study (e.g., Black ${ }^{39}$ Fell, et al. $^{40}$ Ramakrishnan, et al. ${ }^{41}$, Wakiji ${ }^{42}$ ). This fact may explain the popularity of commercially produced citation analysis tools.

Clarivate's Journal Citation Reports (JCR) and Elsevier's CiteScore are commercially produced and similar in that both measure "a ratio between citations and recent citable items published during a particular period of time," ${ }^{43}$ and the ease of use and convenience of each make them attractive options for journal evaluation. Amongst the differences between the two is that $J C R$ calculates both a two-year and a five-year Impact Factor (IF) for selected journals; while CiteScore calculates its ratio in a four-year window, arguing that doing so makes "the calculation more robust and stable." ${ }^{44}$ Another distinction between the two that is worth noting here is that JCR defines 
"citable items" as "articles and reviews," 45 while in 2020 CiteScore updated its definition of citable items to include only "peer-reviewed publication types (articles, reviews, conference papers, book chapters and data papers)." ${ }^{46}$ Also, the level of selectivity between the JCR and CiteScore is considerably different, with the total number of journals assigned an IF standing at $12,030^{47}$ while the number of titles assigned a CiteScore is more than $41,000 .{ }^{48}$ Indeed, more than 13,000 titles have been assigned CiteScores in 2019 that do not have a JCR Impact Factor. ${ }^{49}$ Finally, while accessing JCR data requires a subscription, the CiteScore data is currently available (and downloadable in spreadsheet format) for free.

Because JCR has been available for more than forty years than CiteScore much of the available literature focusing on these two commercially produced citation analyses examines the perceived strengths and weaknesses of Clarivate's $J C R$ citation analysis tool. ${ }^{50}$ Because $J C R$ has been such an important tool for journal evaluation for so long, by the late $20^{\text {th }}$ century it had come to be seen as something of an authority for that purpose. ${ }^{51}$ Meanwhile, others have highlighted the fact that the "unbiased" nature of the data gives JCR an appearance of objectivity 52 and a "demonstrably . . empirical basis" for collection development decisions, ${ }^{53}$ thereby enabling librarians to construct core journal lists on their own. While no similar arguments in the literature have been explicitly made about CiteScore, its use of data is very similar to JCR. Despite all of the perceived advantages that commercially produced citation analyses offer, criticism of the reports and IF, has been unrelenting. For example, Nisonger argues that the methods employed to calculate the IF are advantageous to older, established journals. ${ }^{54}$ More recently, $\mathrm{Su}$, et al. have argued that the use of statistical metrics in assessing journal quality "should be considered with due caution." 55 An extension of that argument can be found in Malsch and Tessier, in which they contend that the methods used to categorize and rank journals by JCR (and by inference CiteScore) suppress impact scores of publications in particular disciplines. ${ }^{56}$ Issues related to the inflation of a journal's impact score, either unintentional or otherwise, have been widely discussed, including citation stacking (e.g., Chakraborty, Pradhan and $\mathrm{Nandi}^{57}$, Lariviere and Sugiomoto ${ }^{58}$, Hayatdavoudi and Haghighat $^{59}$, Heneberg ${ }^{60}$ ) and self-citation (Budimir, et al. ${ }^{61}$, DeJong and St. George ${ }^{62}$, Lăzăroiu $^{63}$ ). Though Walters argues that concerns over self-citation may be overblown ${ }^{64}$, at least one suggestion of a modified CiteScore has been made, ${ }^{65}$ and Clarivate has taken steps to punish journals found to have intentionally manipulated their IF. ${ }^{66}$

\section{Methodology}

This study's ultimate goal was to identify journals core to Criminal Justice by adopting a mixedmethods approach that incorporates the strengths of several methods traditionally employed for building a list of core titles while also ameliorating their weaknesses. Further, we sought to use a technique that would yield reliable results, which could be completed with relative ease, and in a reasonable amount of time. Further, we sought an approach that considered a diverse population of titles. To that end, we adopted the approach used successfully in identifying core journals in Social Work ${ }^{67}$ and Educational Psychology. ${ }^{68}$ That approach used five sources -- two abstracting $\&$ indexing sources, two citation analysis sources, and the authoritative source for subject access used by libraries worldwide -- to construct individual lists of Criminal Justice journal titles from each of those sources. As it relates to the number of sources used, it is worth noting that the 
methodology on which this study is based is not prescriptive, i.e. the number of sources to be used is entirely at the discretion of the person constructing the list.

The journal titles on each of the lists were then assessed for particular characteristics, with titles lacking any of those characteristics eliminated from consideration as a potential core title. Finally, the lists were compared and contrasted, thereby creating tiers of agreement, with the result being a stratified list of titles. In our approach, those titles included on all five lists represent the journals most essential to the discipline, and titles included on four of the lists or three of the lists constitute the balance of the core of Criminal Justice journals. Meanwhile, titles on only two of the five lists are considered optional, i.e., they may be of value depending upon the research focus of an individual scholar or department but are not part of the core. Finally, titles appearing on only one list fall outside of the core.

Since our focus was Criminal Justice journals, the first sources consulted were two relevant abstracting \& indexing (A\&I) services in the discipline, EBSCO's Criminal Justice Abstracts (CJA) and ProQuest's Criminal Justice Database (CJD). According to EBSCO, CJA "is the leading bibliographic database for criminal justice and criminology research" and offers "cover-to-cover indexing of more than 600 journals." 69 Meanwhile, Criminal Justice Database (CJD) is described by ProQuest as "a comprehensive database supporting research on crime, its causes and impacts, legal and social implications, as well as litigation and crime trends."70 Each database's title coverage lists was obtained, and every title on each of the coverage lists was assessed for specific characteristics. Those characteristics were as follows:

- That journals be actively publishing (i.e., the title has not ceased publication),

- That articles be peer-reviewed,

- That the journal has an ISSN number,

- That the journal publishes at least two issues annually.

Titles from either A\&I service that lacked any of these characteristics were excluded from further consideration. Also, because our research focuses on core journal titles, items included in either A\&I service that were not journals (e.g., monographic series) were excluded. Ulrichsweb, Global Serials Directory, a subscription service from ExLibris, was used to clarify where questions arose. This process led to the construction of two separate lists, one for each A\&I service, of journal titles to be considered for inclusion amongst core titles. The $C J A$ list included 436 titles, and the $C J D$ list had 395.

The next step in this process was extracting titles from two citation analysis tools. JCR's annual Impact Factors (IF) for journals are calculated by dividing the total number of citations a journal receives in a given calendar year by the total number of "substantive articles"71 published by that journal during the previous two or five calendar years. The result is a two-year and five-year IF for a selected group of journals. ${ }^{72}$ Creating a JCR title list was as simple as downloading the JCR specific to its "Criminology \& Penology" category. The 69 titles included in that category were then reviewed for the same characteristics as the titles from the A\&I sources (i.e., actively publishing, peer review, assignment of an ISSN, and frequency of publication). Two of the included titles were found to publish annually (Annual Review of Criminology, and Crime and Justice: A Review of Research), and each was excluded from further consideration, even though Annual Review of Criminology has the highest IF of any of the 69 titles in the "Criminology \& Penology" category, and Crime and Justice: A Review of Research is 19th. 
The other citation analysis tool, CiteScore, is calculated by counting "peer-reviewed publication types (articles, reviews, conference papers, book chapters and data papers) in both the citation numerator and publication denominator" during the "the four years up to and including the calculation year." 73 The most current CiteScore data was downloaded in a multi-tab spreadsheet format that included more than 40,000 lines of data. To make the process of reviewing the available data easier several spreadsheet filters were activated. For example, only publications with a status of "active" were displayed. Also, titles with a 2019 CiteScore of 0.0 were excluded from consideration for the core. Next, "source type" data was limited to "journals," thereby eliminating "book series" and "trade journals." Unlike $J C R$, there is no specific criminal justice category in CiteScore. Instead, Scopus has developed its own classification scheme, the All Science Journal Classification Code, ${ }^{74}$ and has assigned each serial publication at least one subject term, with journals often assigned more than one ASJC designation. The closest correlate to criminal justice in this schema is "Law" (ASJC 3308). Therefore, in filtering the ASJC information, all journal titles assigned the code number 3308 were included. The result was a list of 615 titles to be considered for possible inclusion in a core list. A review of those titles was then undertaken to ensure each possessed the necessary characteristics (i.e., peer review, ISSN number, frequency of publication). As a result of that review, the determination was made that several titles were published annually and, according to Ulrich's, at least one title has ceased publication (Journal of Medical Ethics and History of Medicine, ISSN 2008-0387). The net number of journal titles on the CiteScore list following that review was 599.

The fifth and final resource from which titles were drawn was the Library of Congress Subject Headings $(\mathrm{LCSH})$. It has been argued that controlled vocabulary lists allow information seekers to retrieve information more efficiently and are critical for efficiently retrieving and using knowledge. ${ }^{75}$ Further, while some have argued that keyword searching has supplanted subject headings as the de facto method for organizing knowledge, a 2015 study discovered that more than $25 \%$ of keyword search results would be lost if not for the presence of $\mathrm{LCSH}^{76}$ The Library of Congress Subject Headings has been described as one of "the most well-known subject heading lists for the whole field of knowledge" ${ }^{77}$ and is now in its 42 nd edition. ${ }^{78}$ Finally, the precise scope of individual subject headings allows for a level of selectivity that, while helpful, can eliminate journals that are complementary to the discipline.

After a review of the pertinent Library of Congress Subject Headings, the decision was made to search for all journals assigned the $L C S H$ "Criminal justice, Administration of -" or "Criminology" using the advanced search option of the Library of Congress (LOC) public-facing catalog. Also built into the search was a Boolean "not" statement so as to exclude items whose record included the phrase "annual," "irregular," "biennial," or "ceased." The search parameters were limited under "type of material" to "periodical or newspaper." The total number of items yielded by this search was 489. Those titles were then reviewed to ensure the presence of an ISSN number, that each item was a journal, that the journal is peer-reviewed, and that it publishes at least two issues annually. The result of the review was that 95 titles remained, and it was those 95 that were considered for inclusion amongst the core journals for Criminal Justice. 
Figure 1: Methodology Workflow

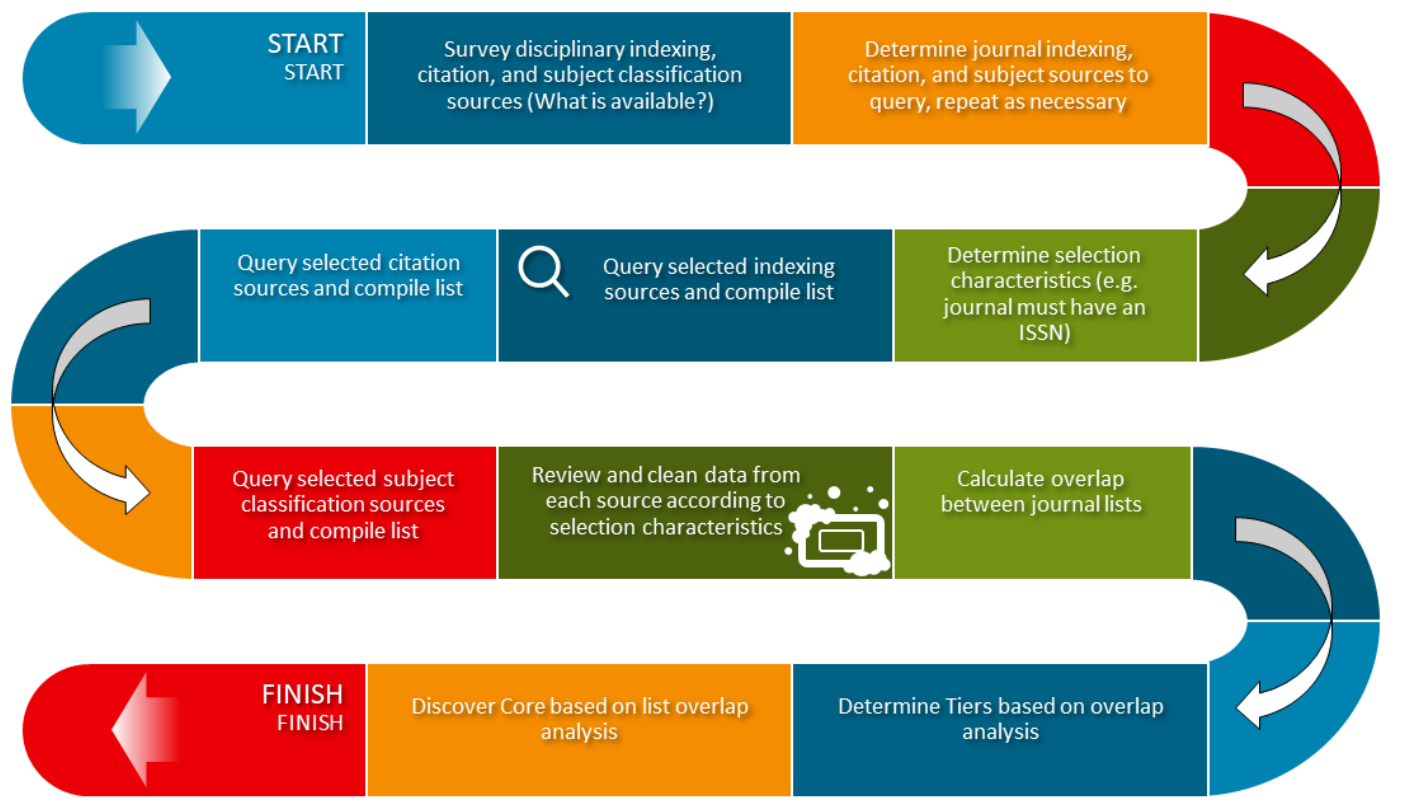

While this methodology aims to create a tiered list of journals, it is not intended to create journal rankings. Therefore, the next step in the process was to compare and contrast the titles included on each of the five individual lists (i.e., CJA, CJD, JCR, CiteScore, and LCSH). The overlap between the lists explains why the universe of titles to be considered for the core is 990 (the complete list of those titles can be found online at $10.6084 / \mathrm{m} 9$.figshare.14498526), though the total sum of titles on the five lists is 1,592 (i.e., 436 titles on the CJA list, 395 on CJD, 599 on CiteScore, 67 on JCR, and 95 on LCSH).

\section{Results}

The core list of journals was comprised of the top three tiers out of the five tiers created by comparing the five title lists. The sources consulted to construct these stratified tiers of journal titles were: Two abstracting \& indexing services (Criminal Justice Abstracts and Criminal Justice Database), two citations analysis sources (CiteScore and Journal Citation Reports), and the preeminent English-language knowledge organization schema, the Library of Congress Subject Headings $(\mathrm{LCSH})$. Lists of titles were created from each source and then compared to one another for overlap, thereby creating a stratified tier list from which a core could be discerned. The relative sizes of each tier and the size of the core compared with the periphery are visible in Figure 2. 
Figure 2: Core Proportion to Periphery

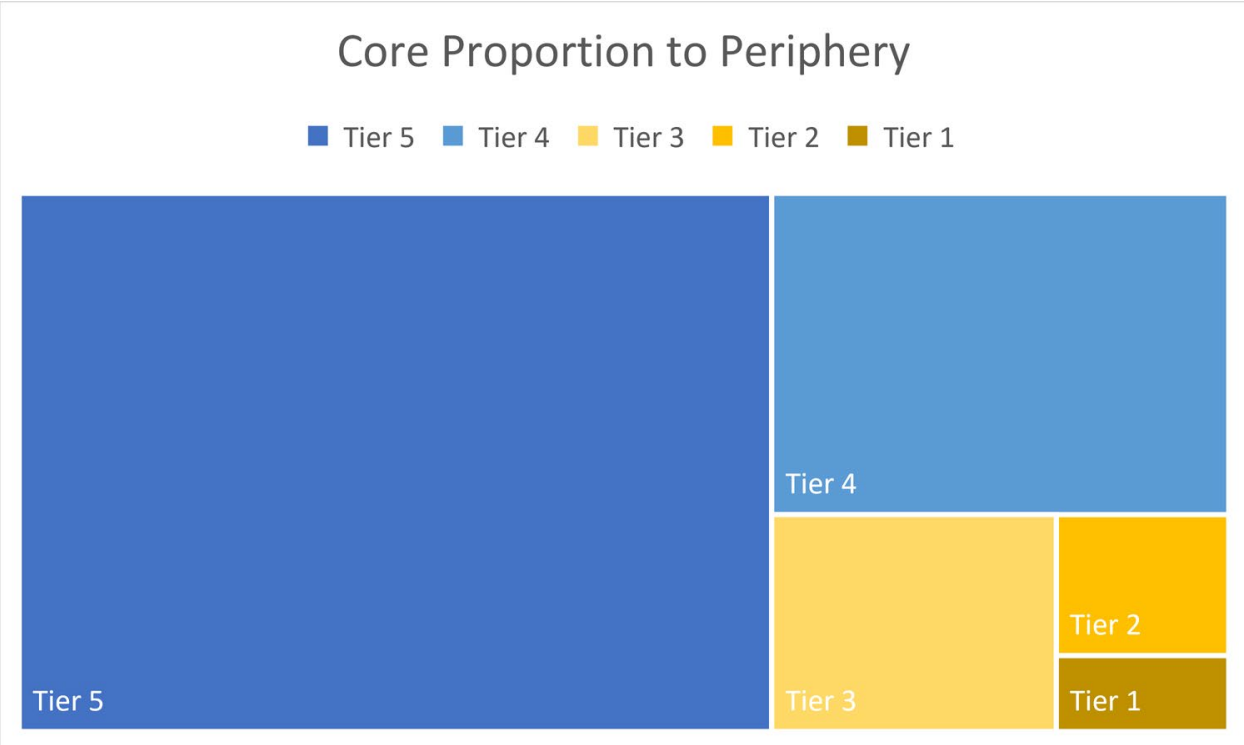

As a result of this methodology, of the 990 titles considered for inclusion, only 151 are considered core to the discipline (a complete alphabetically arranged list of the core titles is available at $10.6084 / \mathrm{m} 9$.figshare.14402513). Of that number, essential titles are those that appeared on each of the five source lists, and it is these 20 titles that comprise Tier 1 (see Table 1). Of note, at this level, $29.85 \%$ of the $J C R$ titles included by this method are at this essential tier. Further, ten of the JCR titles in Tier 1 are amongst those titles with top-20 Impact Factors. Meanwhile, only $3.34 \%$ of the 599 CiteScore titles this methodology includes for constructing a core list are tier one titles. Still, the median CiteScore is 3.7, the highest median CiteScore of all five tiers.

Table 1: Criminal Justice and Criminology at the Core

\begin{tabular}{|l|l|l|l|l|l|l|l|}
\hline Title & ISSN & eISSN & $\begin{array}{l}\text { Criminal } \\
\text { Justice } \\
\text { Abstracts }\end{array}$ & CiteScore & JCR & $\begin{array}{l}\text { LCSH } \\
\text { Criminal } \\
\text { Justice } \\
\text { Database }\end{array}$ \\
\hline $\begin{array}{l}\text { American Journal of Criminal Justice : } \\
\text { AJCJ }\end{array}$ & $1066-2316$ & $1936-1351$ & Core & 2.3 & 1.181 & X & X \\
\hline British Journal of Criminology, The & $0007-0955$ & $1464-3529$ & Core & 5.3 & 2.632 & X & X \\
\hline Crime and Delinquency & $0011-1287$ & $1552-387 X$ & Core & 3.8 & 2.188 & X & X \\
\hline Crime Law and Social Change & $0925-4994$ & $1573-0751$ & Core & 1.9 & 0.921 & X & X \\
\hline Criminology & $0011-1384$ & $1745-9125$ & Core & 5.6 & 3.879 & X & X \\
\hline Criminology \& Criminal Justice & $1748-8958$ & $1748-8966$ & Core & 3.6 & 1.809 & X & X \\
\hline Criminology \& Public Policy & $1538-6473$ & $1745-9133$ & Core & 6.0 & 2.040 & X & X \\
\hline Critical Criminology & $1205-8629$ & $1572-9877$ & Core & 2.5 & 1.149 & X & X \\
\hline European Journal of Criminology & $1477-3708$ & $1741-2609$ & Core & 4.2 & 1.671 & X & X \\
\hline
\end{tabular}




\begin{tabular}{|l|l|l|l|l|l|l|l|}
\hline $\begin{array}{l}\text { European Journal on Criminal Policy } \\
\text { and Research }\end{array}$ & $0928-1371$ & $1572-9869$ & Core & 2.6 & 1.397 & $\mathrm{X}$ & $\mathrm{X}$ \\
\hline Feminist Criminology & $1557-0851$ & $1557-086 \mathrm{X}$ & Core & 2.4 & 1.535 & $\mathrm{X}$ & $\mathrm{X}$ \\
\hline $\begin{array}{l}\text { International Journal of Law, Crime } \\
\text { and Justice }\end{array}$ & $1756-0616$ & $1876-763 \mathrm{X}$ & Core & 1.5 & 0.773 & $\mathrm{X}$ & $\mathrm{X}$ \\
\hline $\begin{array}{l}\text { Journal of Contemporary Criminal } \\
\text { Justice }\end{array}$ & $1043-9862$ & $1552-5406$ & Core & 2.8 & 1.111 & $\mathrm{X}$ & $\mathrm{X}$ \\
\hline Journal of Crime \& Justice & $0735-648 \mathrm{X}$ & $2158-9119$ & Core & 2.1 & 1.159 & $\mathrm{X}$ & $\mathrm{X}$ \\
\hline Journal of Criminal Justice & $0047-2352$ & $1873-6203$ & Core & 4.8 & 2.935 & $\mathrm{X}$ & $\mathrm{X}$ \\
\hline $\begin{array}{l}\text { Journal of Criminal Law \& } \\
\text { Criminology, The }\end{array}$ & $0091-4169$ & $2160-0325$ & Core & 2.2 & 1.333 & $\mathrm{X}$ & $\mathrm{X}$ \\
\hline Journal of Experimental Criminology & $1573-3750$ & $1572-8315$ & Core & 5.1 & 2.308 & $\mathrm{X}$ & $\mathrm{X}$ \\
\hline Journal of Quantitative Criminology & $0748-4518$ & $1573-7799$ & Core & 6.8 & 3.423 & $\mathrm{X}$ & $\mathrm{X}$ \\
\hline Justice Quarterly & $0741-8825$ & $1745-9109$ & Core & 6.0 & 2.802 & $\mathrm{X}$ & $\mathrm{X}$ \\
\hline Theoretical Criminology & $1362-4806$ & $1461-7439$ & Core & 4.0 & 2.818 & $\mathrm{X}$ & $\mathrm{X}$ \\
\hline
\end{tabular}

The 37 titles on four of the five lists comprise Tier 2 (see Table 2). Though not as essential as tier one, the titles at this tier are very much a part of the core journal titles for criminal justice and criminology. At this level, CiteScore, Criminal Justice Abstracts, and Criminal Justice Database each includes 35 titles, though each one excludes different titles. For example, EBSCO's $C J A$ does not include Asian Journal of Criminology or the Journal of Developmental and Life-Course Criminology. Meanwhile, ProQuest's CJD excludes the Australian and New Zealand Journal of Criminology and Monatsschrift für Kriminologie und Strafrechtsreform. As for Scopus' CiteScore, while a 2019 CiteScore is available for the International Journal of Offender Therapy and Comparative Criminology (2.4) rather than including that title as part of the "Law" category (ASJC 3308), CiteScore has categorized it within three other categories: "Arts and Humanities (miscellaneous)" (ASJC 1201), "Medicine, Pathology and Forensic" (ASJC 2734), and "Psychology, Applied Psychology" (ASJC 3202). Also excluded from the "Law" category is the Journal of Research in Crime \& Delinquency (2019 CiteScore 5.4), which is categorized within just one category -- "Psychology, Social Psychology" (ASJC 3207). At this tier JCR includes 26 titles (70.3\%), with only three of those amongst the top 20 Impact Factors and a median IF of 1.2. Finally, $L C S H$ includes just 17 titles, and the precise nature of $L C S H$ has a qualitative impact. For example, searching for titles with the LCSH "Criminal justice, Administration of --" or "Criminology," meant that the journal Crime, Media, Culture fell outside of the titles included on this list (i.e., its $L C S H$ is "Crime in mass media--Periodicals" et al.). While the exclusion of that title may be reasonable, others seem less so. For instance, the LCSH assigned to Punishment \& Society: International Journal of Penology are "Punishment--Periodicals," "Corrections-Periodicals," and "Crime--Sociological aspects--Periodicals." The narrowly focused nature of LCSH leaves this title, which has the highest Impact Factor in this tier (2.648) and a CiteScore (3.8) that is almost twice the median, outside of tier one. 
Table 2: Criminal Justice and Criminology at the Core

\begin{tabular}{|c|c|c|c|c|c|c|c|}
\hline Title & ISSN & eISSN & $\begin{array}{l}\text { Criminal } \\
\text { Justice } \\
\text { Abstracts }\end{array}$ & CiteScore & JCR & LCSH & $\begin{array}{l}\text { Criminal } \\
\text { Justice } \\
\text { Database }\end{array}$ \\
\hline Asian Journal of Criminology & $1871-0131$ & 1871-014X & & 1.5 & 1.06 & $\mathrm{X}$ & $\mathrm{X}$ \\
\hline $\begin{array}{l}\text { Australian and New Zealand Journal of } \\
\text { Criminology }\end{array}$ & $0004-8658$ & $1837-9273$ & Core & 2.3 & 1.32 & $\mathrm{X}$ & \\
\hline $\begin{array}{l}\text { Canadian Journal of Criminology and } \\
\text { Criminal Justice }\end{array}$ & & 1911-0219 & Core & 1.2 & 0.58 & & $\mathrm{X}$ \\
\hline Contemporary Justice Review & $1028-2580$ & $1477-2248$ & Core & 1.2 & & $\mathrm{X}$ & $\mathrm{X}$ \\
\hline Crime Media Culture & $1741-6590$ & & Core & 3.5 & 1.75 & & $\mathrm{X}$ \\
\hline Criminal Justice and Behavior & $0093-8548$ & $1552-3594$ & Core & 3.6 & 1.52 & & $\mathrm{X}$ \\
\hline Criminal Justice Ethics & $0731-129 \mathrm{X}$ & $1937-5948$ & Core & 0.5 & & $\mathrm{X}$ & $\mathrm{X}$ \\
\hline Criminal Justice Policy Review & $0887-4034$ & $1552-3586$ & Core & 2.8 & & $\mathrm{X}$ & $\mathrm{X}$ \\
\hline Criminal Justice Review & $0734-0168$ & $1556-3839$ & Core & 1.6 & & $\mathrm{X}$ & $\mathrm{X}$ \\
\hline Deviant Behavior & $0163-9625$ & $1521-0456$ & Core & 2.6 & 1.35 & & $\mathrm{X}$ \\
\hline $\begin{array}{l}\text { European Journal of Crime, Criminal Law } \\
\text { and Criminal Justice }\end{array}$ & $0928-9569$ & $1571-8174$ & Core & 1.4 & & $\mathrm{X}$ & $\mathrm{X}$ \\
\hline Homicide Studies & $1088-7679$ & $1552-6720$ & Core & 2.4 & 1.64 & & $\mathrm{X}$ \\
\hline $\begin{array}{l}\text { International Journal of Comparative and } \\
\text { Applied Criminal Justice }\end{array}$ & $0192-4036$ & $2157-6475$ & Core & 1.6 & & $\mathrm{X}$ & $\mathrm{X}$ \\
\hline $\begin{array}{l}\text { International Journal of Criminal Justice } \\
\text { Sciences }\end{array}$ & 0973-5089 & & Core & 0.3 & & $\mathrm{X}$ & $\mathrm{X}$ \\
\hline $\begin{array}{l}\text { International Journal of Offender Therapy } \\
\text { and Comparative Criminology }\end{array}$ & $0306-624 \mathrm{X}$ & $1552-6933$ & Core & & 1.03 & $\mathrm{X}$ & $\mathrm{X}$ \\
\hline Journal of Criminal Justice Education & $1051-1253$ & $1745-9117$ & Core & 1.2 & & $\mathrm{X}$ & $\mathrm{X}$ \\
\hline $\begin{array}{l}\text { Journal of Developmental and Life- } \\
\text { Course Criminology }\end{array}$ & $2199-4641$ & $2199-465 X$ & & 2.2 & 1.11 & $\mathrm{X}$ & $\mathrm{X}$ \\
\hline Journal of Offender Rehabilitation & $1050-9674$ & $1540-8558$ & Core & 1.3 & & $\mathrm{X}$ & $\mathrm{X}$ \\
\hline $\begin{array}{l}\text { Journal of Research in Crime \& } \\
\text { Delinquency, The }\end{array}$ & $0022-4278$ & $1552-731 X$ & Core & & 2.52 & $\mathrm{X}$ & $\mathrm{X}$ \\
\hline $\begin{array}{l}\text { Monatsschrift für Kriminologie und } \\
\text { Strafrechtsreform }\end{array}$ & $0026-9301$ & & Core & 0.4 & 0.23 & $\mathrm{X}$ & \\
\hline New Criminal Law Review & $1933-4192$ & $1933-4206$ & Core & 1.3 & & $\mathrm{X}$ & $\mathrm{X}$ \\
\hline Police Quarterly & $1098-6111$ & & Core & 4.7 & 1.5 & & $\mathrm{X}$ \\
\hline Policing \& Society & $1043-9463$ & $1477-2728$ & Core & 3.4 & 1.66 & & $\mathrm{X}$ \\
\hline Policing: A Journal of Policy \& Practice & $1752-4512$ & $1752-4520$ & Core & 2.9 & 1.79 & & $\mathrm{X}$ \\
\hline $\begin{array}{l}\text { Policing: An International Journal Of } \\
\text { Police Strategies \& Management }\end{array}$ & $1363-951 X$ & & Core & 1.76 & 1.19 & & $\mathrm{X}$ \\
\hline Prison Journal, The & $0032-8855$ & $1552-7522$ & Core & 1.5 & 0.86 & & $\mathrm{X}$ \\
\hline Probation Journal & $0264-5505$ & $1741-3079$ & Core & 2.2 & & $\mathrm{X}$ & $\mathrm{X}$ \\
\hline Psychology Crime \& Law & $1068-316 \mathrm{X}$ & $1477-2744$ & Core & 3.1 & 1.19 & & $\mathrm{X}$ \\
\hline $\begin{array}{l}\text { Punishment \& Society: International } \\
\text { Journal of Penology }\end{array}$ & $1462-4745$ & $1741-3095$ & Core & 3.8 & 2.65 & & $\mathrm{X}$ \\
\hline Security Journal & $0955-1662$ & $1743-4645$ & Core & 2.3 & 0.84 & & $\mathrm{X}$ \\
\hline Social \& Legal Studies & $0964-6639$ & $1461-7390$ & Core & 2 & 1.22 & & $\mathrm{X}$ \\
\hline Trends in Organized Crime & $1084-4791$ & $1936-4830$ & Core & 2.1 & 1.25 & & $\mathrm{X}$ \\
\hline Victims \& Offenders & $1556-4886$ & $1556-4991$ & Core & 2.5 & 1.12 & & $\mathrm{X}$ \\
\hline Violence and Victims & $0886-6708$ & $1945-7073$ & Core & 1.6 & 0.6 & & $\mathrm{X}$ \\
\hline Women \& Criminal Justice & $0897-4454$ & $1541-0323$ & Core & 1.6 & 0.88 & & $\mathrm{X}$ \\
\hline Youth Justice: An International Journal & $1473-2254$ & $1747-6283$ & Core & 1.4 & 1.23 & & $\mathrm{X}$ \\
\hline
\end{tabular}




\begin{tabular}{|l|l|l|l|l|l|l|l|}
\hline Youth Violence And Juvenile Justice & $1541-2040$ & $1556-9330$ & Core & 4.4 & 2.18 & & $\mathrm{X}$ \\
\hline
\end{tabular}

Tier three is comprised of those journal titles included in three of the five source lists, and this group of 94 titles completes the list of core titles (see Table 3). At this level $C J A$ includes 91 titles, just over $20 \%$ of all titles indexed and abstracted by $C J A$ and the third-highest percentage for $C J A$ at any tier. $C J D$ also includes 91 titles, the second-highest number at any tier for $C J D$, and $23.45 \%$ of all titles indexed and abstracted by CJD. At this level, JCR includes 14 titles, more than $20 \%$ of all JCR titles, and the second-lowest number of all the tiers. Meanwhile, CiteScore includes 74 titles, the second-highest number for this list. Of the 20 titles at this tier that CiteScore does not include, 12 have a 2019 CiteScore, (median score 3.7) but have not been assigned to the "Law" category. These titles include Journal of Interpersonal Violence (CiteScore of 4.1, categorized in "Psychology, Clinical Psychology" and "Psychology, Applied Psychology"), Journal of Investigative Psychology and Offender Profiling (2.2, "Psychology, Social Psychology" and "Psychology, Applied Psychology"), Journal of School Violence (3.3, "Social Science, Education" and "Engineering, Safety, Risk, Reliability and Quality"), and Legal and Criminological Psychology (4.5, "Medicine, Pathology and Forensic Medicine" and "Psychology, Applied Psychology"). Also of interest is that there are only two titles that CiteScore and JCR share in common: Psychiatry Psychology and Law and Revija Za Kriminalistiko in Kriminologijo. Finally, $L C S H$ includes only 12 titles. At this tier, the impact of the limited scope of individual LCSH comes into full relief. For example, though Police Practice and Research has been assigned multiple subject headings ("Police--Periodicals," Police administration--Periodicals," "Law enforcement--Periodicals," "Crime prevention--Periodicals"), the decision to search for journals using broader $L C S H$ left this title, and a multitude of others, off the $L C S H$ list and moved them from Tier 2 to Tier 3.

Table 3: Criminal Justice and Criminology at the Core

\begin{tabular}{|c|c|c|c|c|c|c|c|}
\hline Title & ISSN & eISSN & $\begin{array}{l}\text { Criminal } \\
\text { Justice } \\
\text { Abstracts }\end{array}$ & CiteScore & JCR & LCSH & $\begin{array}{l}\text { Criminal } \\
\text { Justice } \\
\text { Database }\end{array}$ \\
\hline $\begin{array}{l}\text { African Journal of Criminology and } \\
\text { Justice Studies : AJCJS }\end{array}$ & & $1554-3897$ & Core & & & $\mathrm{X}$ & $\mathrm{X}$ \\
\hline Aggression and Violent Behavior & $1359-1789$ & $1873-6335$ & Core & & 2.893 & & $\mathrm{X}$ \\
\hline American Journal of Law \& Medicine & $0098-8588$ & $2375-835 X$ & Core & 1.5 & & & $\mathrm{X}$ \\
\hline American University Law Review & $0003-1453$ & & Core & 1.17 & & & $\mathrm{X}$ \\
\hline Behavioral Sciences \& the Law & $0735-3936$ & & Core & 1.8 & & & $\mathrm{X}$ \\
\hline British Journal of Community Justice & $1475-0279$ & & Core & 0.8 & & & $\mathrm{X}$ \\
\hline California Law Review & $0008-1221$ & & Core & 2.7 & & & $\mathrm{X}$ \\
\hline Cambridge Law Journal, The & $0008-1973$ & $1469-2139$ & Core & 0.9 & & & $\mathrm{X}$ \\
\hline $\begin{array}{l}\text { Canadian Journal of Law \& } \\
\text { Society/Revue Canadienne Droit et } \\
\text { Societe (Cambridge University Press) }\end{array}$ & 0829-3201 & $1911-0227$ & Core & 0.6 & & & $\mathrm{X}$ \\
\hline Canadian Journal of Women \& the Law & $0832-8781$ & $1911-0235$ & Core & 1.1 & & & $\mathrm{X}$ \\
\hline Child Abuse Review & $0952-9136$ & $1099-0852$ & Core & 3.3 & & & $\mathrm{X}$ \\
\hline CJM : Criminal Justice Matters & $0962-7251$ & $1934-6220$ & Core & & & $\mathrm{X}$ & $\mathrm{X}$ \\
\hline
\end{tabular}




\begin{tabular}{|c|c|c|c|c|c|c|c|}
\hline $\begin{array}{l}\text { Columbia Journal of Law \& Social } \\
\text { Problems }\end{array}$ & $0010-1923$ & & Core & 0.3 & & & $\mathrm{X}$ \\
\hline Columbia Law Review & $0010-1958$ & $1945-2268$ & Core & 2.1 & & & $\mathrm{X}$ \\
\hline Computers \& Security & $0167-4048$ & $1872-6208$ & Core & 7.5 & & & $\mathrm{X}$ \\
\hline Conflict Resolution Quarterly & $1536-5581$ & $1541-1508$ & Core & 1.8 & & & $\mathrm{X}$ \\
\hline Contemporary Drug Problems & $0091-4509$ & $2163-1808$ & Core & 3 & & & $\mathrm{X}$ \\
\hline Cornell Law Review & $0010-8847$ & & Core & 2.3 & & & $\mathrm{X}$ \\
\hline Crime Prevention \& Community Safety & $1460-3780$ & $1743-4629$ & Core & 1.2 & & & $\mathrm{X}$ \\
\hline Crime Science & $2193-7680$ & & Core & 3.6 & & & $\mathrm{X}$ \\
\hline Criminal Behaviour and Mental Health & $0957-9664$ & $1471-2857$ & Core & & 1.221 & & $\mathrm{X}$ \\
\hline Criminal Justice Studies & $1478-601 X$ & $1478-6028$ & Core & 1.4 & & & $\mathrm{X}$ \\
\hline Criminal Law \& Philosophy & $1871-9791$ & $1871-9805$ & Core & 1.3 & & & $\mathrm{X}$ \\
\hline Criminal Law Forum & $1046-8374$ & $1572-9850$ & Core & 0.7 & & & $\mathrm{X}$ \\
\hline Derecho Penal y Criminología & $0121-0483$ & $2346-2108$ & Core & & & $\mathrm{X}$ & $\mathrm{X}$ \\
\hline Digital Investigation & $1742-2876$ & $1873-202 X$ & Core & 3.9 & & & $\mathrm{X}$ \\
\hline Dynamics of Asymmetric Conflict & $1746-7594$ & & Core & 1 & & $\mathrm{X}$ & \\
\hline European Journal of International Law & $0938-5428$ & $1464-3596$ & Core & 2.2 & & & $\mathrm{X}$ \\
\hline $\begin{array}{l}\text { Forensische Psychiatrie, Psychologie, } \\
\text { Kriminologie }\end{array}$ & $1862-7072$ & $1862-7080$ & & 0.6 & & $\mathrm{X}$ & $\mathrm{X}$ \\
\hline Global Crime & $1744-0572$ & $1744-0580$ & Core & 2.4 & & & $\mathrm{X}$ \\
\hline Harvard Journal of Law \& Public Policy & $0193-4872$ & & Core & 0.8 & & & $\mathrm{X}$ \\
\hline Health \& Justice & & $2194-7899$ & Core & 2.4 & & & $\mathrm{X}$ \\
\hline $\begin{array}{l}\text { Howard Journal of Crime and Justice, } \\
\text { The }\end{array}$ & $2059-1098$ & $2059-1101$ & & 1.5 & & $\mathrm{X}$ & $\mathrm{X}$ \\
\hline Human Rights Law Review & $1461-7781$ & $1744-1021$ & Core & 1.6 & & & $\mathrm{X}$ \\
\hline $\begin{array}{lll}\text { International \& } & \text { Comparative } & \text { Law } \\
\text { Quarterly, The } & & \\
\end{array}$ & $0020-5893$ & $1471-6895$ & Core & 2 & & & $\mathrm{X}$ \\
\hline International Criminal Justice Review & $1057-5677$ & $1556-3855$ & Core & 1.5 & & & $\mathrm{X}$ \\
\hline International Criminal Law Review & $1567-536 X$ & $1571-8123$ & Core & 1 & & & $\mathrm{X}$ \\
\hline $\begin{array}{l}\text { International Journal for Crime, Justice } \\
\text { \& Social Democracy }\end{array}$ & $2202-7998$ & $2202-8005$ & Core & 2 & & & $\mathrm{X}$ \\
\hline $\begin{array}{l}\text { International Journal of Conflict \& } \\
\text { Violence }\end{array}$ & & $1864-1385$ & Core & 2.1 & & & $\mathrm{X}$ \\
\hline $\begin{array}{llll}\begin{array}{l}\text { International } \\
\text { Criminology }\end{array} & \text { Journal } & \text { of } & \text { Cyber } \\
\end{array}$ & & $0974-2891$ & Core & 2.3 & & & $\mathrm{X}$ \\
\hline $\begin{array}{l}\text { International Journal of Forensic Mental } \\
\text { Health }\end{array}$ & $1499-9013$ & $1932-9903$ & Core & & 1.121 & & $\mathrm{X}$ \\
\hline $\begin{array}{l}\text { International Journal of Law, Policy \& } \\
\text { the Family }\end{array}$ & $1360-9939$ & $1464-3707$ & Core & 1.5 & & & $\mathrm{X}$ \\
\hline $\begin{array}{l}\text { Journal of Addictions \& } \quad \text { Offender } \\
\text { Counseling }\end{array}$ & $1055-3835$ & $2161-1874$ & Core & 1.1 & & & $\mathrm{X}$ \\
\hline Journal of Adult Protection, The & $1466-8203$ & $2042-8669$ & Core & 1.6 & & & $\mathrm{X}$ \\
\hline $\begin{array}{l}\text { Journal of Aggression Maltreatment \& } \\
\text { Trauma }\end{array}$ & $1092-6771$ & $1545-083 X$ & Core & & 1.03 & & $\mathrm{X}$ \\
\hline $\begin{array}{l}\text { Journal of Aggression, Conflict \& Peace } \\
\text { Research }\end{array}$ & $1759-6599$ & $2042-8715$ & Core & 1.2 & & & $\mathrm{X}$ \\
\hline Journal of Applied Security Research & $1936-1610$ & $1936-1629$ & Core & 1.2 & & & $\mathrm{X}$ \\
\hline
\end{tabular}




\begin{tabular}{|c|c|c|c|c|c|c|c|}
\hline $\begin{array}{l}\text { Journal of Criminological Research, } \\
\text { Policy and Practice }\end{array}$ & $2056-3841$ & $2056-385 X$ & & 1 & & $\mathrm{X}$ & $\mathrm{X}$ \\
\hline Journal of Empirical Legal Studies & $1740-1453$ & $1740-1461$ & Core & 1.7 & & & $\mathrm{X}$ \\
\hline Journal of Ethnicity in Criminal Justice & $1537-7938$ & $1537-7946$ & Core & 1.1 & & & $\mathrm{X}$ \\
\hline Journal of Family Violence & $0885-7482$ & $1573-2851$ & Core & 2.2 & & & $\mathrm{X}$ \\
\hline Journal of Forensic \& Legal Medicine & $1752-928 X$ & & Core & 2.4 & & & $\mathrm{X}$ \\
\hline Journal of Forensic Practice & $2050-8794$ & $2050-8808$ & Core & 0.7 & & & $\mathrm{X}$ \\
\hline $\begin{array}{l}\text { Journal of Forensic Psychiatry \& } \\
\text { Psychology, The }\end{array}$ & $1478-9949$ & $1478-9957$ & Core & & 1.061 & & $\mathrm{X}$ \\
\hline Journal of International Criminal Justice & $1478-1387$ & $1478-1395$ & Core & 1.4 & & & $\mathrm{X}$ \\
\hline Journal of Interpersonal Violence & $0886-2605$ & $1552-6518$ & Core & & 3.573 & & $\mathrm{X}$ \\
\hline $\begin{array}{l}\text { Journal of Investigative Psychology and } \\
\text { Offender Profiling }\end{array}$ & $1544-4759$ & $1544-4767$ & Core & & 0.783 & & $\mathrm{X}$ \\
\hline Journal of Law \& Economics & $0022-2186$ & $1537-5285$ & Core & 2 & & & $\mathrm{X}$ \\
\hline Journal of Law \& Society & 0263-323X & $1467-6478$ & Core & 1.5 & & & $\mathrm{X}$ \\
\hline $\begin{array}{l}\text { Journal of Law, Economics } \quad \& \\
\text { Organization }\end{array}$ & $8756-6222$ & $1465-7341$ & Core & 2.1 & & & $\mathrm{X}$ \\
\hline Journal of Legal Studies & $0047-2530$ & $1537-5366$ & Core & 2 & & & $\mathrm{X}$ \\
\hline Journal of Money Laundering Control & $1368-5201$ & $1758-7808$ & Core & 1.1 & & & $\mathrm{X}$ \\
\hline Journal of Police \& Criminal Psychology & $0882-0783$ & $1936-6469$ & Core & 2.1 & & & $\mathrm{X}$ \\
\hline Journal of School Violence & $1538-8220$ & $1538-8239$ & Core & & 1.561 & & $\mathrm{X}$ \\
\hline Journal of Sexual Aggression, The & $1355-2600$ & $1742-6545$ & Core & & 0.917 & & $\mathrm{X}$ \\
\hline $\begin{array}{l}\text { Journal of Social Welfare \& Family Law, } \\
\text { The }\end{array}$ & $0964-9069$ & & Core & 0.9 & & & $\mathrm{X}$ \\
\hline $\begin{array}{l}\text { Journal of Theoretical \& Philosophical } \\
\text { Criminology }\end{array}$ & & $2166-8094$ & Core & & & $\mathrm{X}$ & $\mathrm{X}$ \\
\hline Justice Evaluation Journal & $2475-1979$ & $2475-1987$ & Core & & & $\mathrm{X}$ & $\mathrm{X}$ \\
\hline Justice System Journal & $0098-261 X$ & $2327-7556$ & Core & 0.9 & & & $\mathrm{X}$ \\
\hline Juvenile \& Family Court Journal & $0161-7109$ & $1755-6988$ & Core & 0.8 & & & $\mathrm{X}$ \\
\hline Law \& Contemporary Problems & $0023-9186$ & $1945-2322$ & Core & 3.3 & & & $\mathrm{X}$ \\
\hline Law \& Critique & $0957-8536$ & $1572-8617$ & Core & 1.4 & & & $\mathrm{X}$ \\
\hline Law \& History Review & $0738-2480$ & $1939-9022$ & Core & 0.8 & & & $\mathrm{X}$ \\
\hline Law \& Human Behavior & $0147-7307$ & $1573-661 X$ & Core & 4.9 & & & $\mathrm{X}$ \\
\hline Law \& Policy & $0265-8240$ & $1467-9930$ & Core & 2.3 & & & $\mathrm{X}$ \\
\hline Law \& Social Inquiry & $0897-6546$ & $1545-696 \mathrm{X}$ & Core & 1.7 & & & $\mathrm{X}$ \\
\hline Law \& Society Review & $0023-9216$ & $1540-5893$ & Core & 2.6 & & & $\mathrm{X}$ \\
\hline Law, Probability \& Risk & $1470-8396$ & $1470-840 X$ & Core & 2.2 & & & $\mathrm{X}$ \\
\hline Legal And Criminological Psychology & $1355-3259$ & $2044-8333$ & Core & & 1.667 & & $\mathrm{X}$ \\
\hline Modern Law Review, The & $0026-7961$ & $1468-2230$ & Core & 1.8 & & & $\mathrm{X}$ \\
\hline Notre Dame Law Review, The & $0745-3515$ & & Core & 1.6 & & & $\mathrm{X}$ \\
\hline Oxford Journal of Legal Studies & $0143-6503$ & $1464-3820$ & Core & 1.8 & & & $\mathrm{X}$ \\
\hline Pakistan Journal of Criminology & $2074-2738$ & $2222-6648$ & Core & & & $\mathrm{X}$ & $\mathrm{X}$ \\
\hline Police Practice \& Research & $1561-4263$ & $1477-271 X$ & Core & 2 & & & $\mathrm{X}$ \\
\hline Psychiatry Psychology And Law & $1321-8719$ & & Core & 1.4 & 0.664 & & \\
\hline
\end{tabular}




\begin{tabular}{|l|l|l|l|l|l|l|l|}
\hline $\begin{array}{l}\text { Revija Za Kriminalistiko in } \\
\text { Kriminologijo }\end{array}$ & $0034-690 \mathrm{X}$ & & Core & 0.6 & 0.565 & & \\
\hline Safer Communities & $1757-8043$ & $2042-8774$ & Core & 0.9 & & & $\mathrm{X}$ \\
\hline $\begin{array}{l}\text { Sexual Abuse: A Journal Of Research } \\
\text { And Treatment }\end{array}$ & $1079-0632$ & $1573-286 \mathrm{X}$ & Core & & 2.13 & & $\mathrm{X}$ \\
\hline $\begin{array}{l}\text { Social Justice : A Journal of Crime, } \\
\text { Conflict \& World Order }\end{array}$ & $1043-1578$ & $2327-641 \mathrm{X}$ & Core & & & $\mathrm{X}$ & $\mathrm{X}$ \\
\hline Social Justice Research & $0885-7466$ & $1573-6725$ & Core & 2.1 & & & $\mathrm{X}$ \\
\hline State Crime Journal & $2046-6056$ & $2046-6064$ & Core & 0.3 & & & $\mathrm{X}$ \\
\hline Tijdschrift voor Criminologie & $0165-182 \mathrm{X}$ & $2468-9467$ & Core & & & $\mathrm{X}$ & $\mathrm{X}$ \\
\hline Trauma Violence \& Abuse & $1524-8380$ & & Core & & 6.325 & & $\mathrm{X}$ \\
\hline Violence Against Women & $1077-8012$ & $1552-8448$ & Core & 3 & & & $\mathrm{X}$ \\
\hline
\end{tabular}

The 223 titles included on just two of the source lists comprises the fourth tier, and this comparative lack of agreement makes these titles optional rather than part of the core. At this level it is the two abstracting and indexing sources that contribute overwhelmingly. Roughly $45 \%$ of all the titles indexed by $C J A$ are found here, while the corresponding number for $C J D$ is nearly $48 \%$. Moreover, of all the titles at this level, $C J A$ and $C J D$ have 164 in common. Also of interest is the inclusion of specific titles on the CiteScore list. For example, the Journal of Criminal Psychology is assigned to the "Law" category, as well as "Psychology, Social Psychology" and "Psychology, Applied Psychology" (the complete list of titles at this tier is available online at 10.6084/m9.figshare.14510838).

Finally, tier five is comprised of those titles that appear on only one list. Interestingly, almost $70 \%$ of the titles here appear only on the CiteScore list (JCR has no titles at this tier), slightly more than $15 \%$ are on the $C J A$ list, just over $10 \%$ on the CJD list, and $4.38 \%$ are from the $L C S H$ list. While there may be journals of outstanding quality at this level, the absence of any agreement between the five lists means that the 616 titles found here are entirely outside the core.

\section{Discussion}

The purpose of this study was to employ a previously tested, scalable, mixed-methods approach to constructing a core list of criminal justice and criminology journals. Though each of the methods employed in this study is not without shortcomings, we believe that comparing and contrasting the lists of titles derived from each of the five sources ameliorated those. One method that was not employed for this study was that of perceptual rankings, arguably the most laborintensive of all the methods used for constructing core journal lists. To investigate our list's usefulness, we decided to compare the results of this study with the recent study by DeJong and St. George that use survey data to construct its core list and then compared those results with "objective measures." 79 For their study, DeJong and St. George surveyed the membership of the American Society of Criminology and the Academy of Criminal Justice Sciences $(n=4,287)$ and received responses from 543 members. ${ }^{80}$ A key characteristic of the work of DeJong and St. George is that they provided survey respondents with a list of journal titles to rank and assess, a list constructed from journal titles listed in Google Scholar and [JCR] for a total of 46 titles ${ }^{81}$ (by way of comparison, this current study has 151 titles considered core to the discipline). To their credit, the authors are forthcoming concerning the challenges they faced in asking respondents to complete the survey process and caution readers that the rankings may not be entirely reliable. ${ }^{82}$ 
But because DeJong and St. George have compiled one of the longer lists of core titles available in the criminal justice and criminology literature we believe it is still a good benchmark by which to assess our own results.

At first blush, the two core lists appear to match up well. Of the 46 titles identified by DeJong and St. George, 38 (possibly 39) are considered core to the discipline (82.6\%) using this five-list method. In our list, 14 are Tier 1, i.e., the most essential (36.8\%), twelve of the 38 titles are considered Tier $2(31.6 \%$ ), and at least 12 (possibly 13, see below) are considered Tier 3 titles $(31.6 \%)$. Three titles are Tier $4(8 \%)$, making them optional, and a single title is considered Tier 5 , meaning that it is outside of those titles considered core to the discipline. Finally, there are unresolved questions about three others that do not appear on any of the five source lists used to compile the list for this research. A note about the titles not included in the core list seems warranted:

- Crime and Justice: A Review of the Research: According to Ulrich's, this item is published once annually, and as part of the methodology we employed, to be considered for inclusion in the core, items must publish at least two issues annually.

- Social Problems: This is a top ten journal on the DeJong and St. George list but only a Tier 4 journal (i.e., it is considered optional) using the five-list method employed for this study. Despite being indexed by both Criminal Justice Abstracts (CJA) and Criminal Justice Database (CJD), the journal has not been assigned an Impact Factor (IF) nor a CiteScore, and its Library of Congress Subject Headings (LCSH) is "Social problemsPeriodicals." DeJong and St. George mention the question of whether journals that are not strictly focused on Criminal Justice or Criminology should be included in a core list for the discipline. ${ }^{83}$ This title may be one that, while relevant to the discipline, is not of the discipline.

- Social Forces: Ranked tenth by DeJong and St. George, ${ }^{84}$ this is a Tier 5 journal in the current study. Though $C J D$ indexes this title, it is not indexed in $C J A$, is not assigned a CiteScore or an IF, and its $L C S H$ are "Social problems-Periodicals" and "Social service-Periodicals." As with Social Problems, an argument can be made that this title is not central to the discipline.

- Legal and Criminal Psychology: No journal with this exact title was included on our core list. Because the DeJong and St. George study did not include ISSN numbers, searches using Ulrich's, the Library of Congress public catalog advanced search screen, Google Scholar (including journal metrics), and a web search were undertaken. We were unable to identify a journal with that exact title. However, the $J C R$ for both 2017 and 2018 include the journal Legal and Criminological Psychology (eISSN 2044-8333), and that journal is included in our core list at Tier 3. Whether it is the title included by DeJong and St. George is not known for certain, but if so, it would raise the number of titles identified by them that are also included in this core list from 38 to 39 .

- Policing: Once again, no journal with that exact title could be located. The JCR for 2017 and 2018 do include Policing \& Society (eISSN 1477-2827), which is a Tier 2 journal 
using the current methodology

- Journal of Forensic Psychology and Offender Profiling: Using an identical approach to the search for Legal and Criminal Psychology, we could not locate a journal with this exact title. Further, no journal with that title appears in either the $J C R$ for 2017 or 2018.

While it is natural to compare the results of this study to those of disciplinary experts, it is also worth comparing their work to ours. To that end, here are a few of the more than 100 titles included on our list that are not part of the DeJong and St. George list:

- Tier 1

- American Journal of Criminal Justice: AJCJ (IF: 1.181, CiteScore: 2.3)

- Critical Criminology (IF: 1.149, CiteScore: 2.5)

- European Journal on Criminal Policy and Research (IF: 1.397, CiteScore: 2.6)

- Tier 2

- Crime Media Culture (IF: 1.750, CiteScore: 3.5)

- Punishment \& Society: International Journal of Penology (IF: 2.648, CiteScore: 3.8).

- Youth Justice: An International Journal IF: 1.231, CiteScore: 1.4)

\section{- Tier 3}

- Journal of Aggression Maltreatment \& Trauma (IF: 1.030, indexed in CJA and $C J D)$.

- Journal of Forensic Psychiatry \& Psychology (IF: 1.061, indexed in CJA and CJD).

- Journal of Sexual Aggression (IF: 0.917, indexed in CJA and CJD)

Core journal lists constructed by disciplinary experts have always been, and will always be, of considerable value. However, the value of the method employed for this study is that it considers the disciplinary literature more inclusively while still acknowledging qualitative distinctions that are often a part of perceptual rankings.

\section{Limitations}

As noted above, while this study, with its tiered lists, uses a more rigorous and novel method than previous studies looking at the criminal justice and criminology fields, there remain some caveats and limits. Usage, particularly by practitioners and scholars in the field but also by students is incredibly important. This study did not collect or take any usage data into account and, therefore, should not be used in isolation for any speculative collection development purposes. The process of attempting to quantify "quality" requires several assumptions and has been subject to a variety of criticisms summarized in the literature review. Of particular note for readers is the absence of a CiteScore category for criminology or criminal justice. This study used the "Law" category. Law, legal studies, and criminology are not synonymous, and their intersections are a source of debate over the scope of what criminal justice is as a field. Also, a 2016 study demonstrated that over time the amount of legal scholarship in criminology journals had decreased considerably. ${ }^{85}$ While the obverse is not necessarily true, we could not find literature speaking to the question one way or the other and thus note the possibility that a different quality indicator with an explicit "Criminal Justice" category might prove a superior source. One categorization option that does include Criminology is the Field of Research (FoRs) section of the Australian and New Zealand Standard Research Classification used by the Excellence in Research for Australia (ERA) framework. 
Alternative journal metrics as a substitute for CiteScore in future research are mentioned below. As noted above in the Methodology and Results sections, the total universe of titles included on any one of the source lists was 1,592, but only 990 were overlapping, suggesting that subject classification as a general enterprise remains publisher-specific, inconsistent, and subjective.

\section{Conclusion}

The sheer numbers of core journal lists across many disciplines, including criminal justice and criminology, that have been created speak to a seemingly inexhaustible desire to identify those journals that consistently publish the most meaningful scholarship. Many of the methods used to create lists, particularly perceptual rankings, and citation analyses, are labor-intensive, making them difficult to update regularly. This study employed a methodology previously tested in Social Work and Educational Psychology, which relied upon the collective judgment of two leading abstracting \& indexing services in criminal justice, two commercial citation analysis tools, and a respected and selective controlled vocabulary schema. That method produced a list of 151 journal titles that are considered core to criminal justice and criminology. These results are consistent with a list created by experts in the discipline while being more inclusive of other relevant journals. Importantly, in addition to producing reliable results, the work of creating the core list is manageable in both size and scope.

The method we have employed has produced encouraging results across multiple disciplines and is an approach that others can use with some confidence. An area of future research that may advance the method is incorporating other journal metric tools (e.g., Eigenfactor, SCImago Journal \& Country Rank, Google Scholar Metrics, ERA FoRs) in direct comparison to, or as replacements for, JCR or CiteScore. Librarians responsible for collection development in criminal justice or criminology are encouraged to make all reasonable efforts to bring access to the 151 core journal titles for these areas to their students and faculty.

\section{Data availability statement}

The data that support the findings of this study are openly available in figshare at https://doi.org/10.6084/m9.figshare.14498526. 


\section{Notes}

${ }^{1}$ David Laband, "On the Use and Abuse of Economics Journal Rankings," The Economic Journal 123, no. 570 (2013): F223-F254. https://doi.org/10.1111/ecoj.12067.

${ }^{2}$ Stella M. Nkomo, "The Seductive Power of Academic Journal Rankings: Challenges of Searching for the Otherwise," Academy of Management Learning \& Education 8, no. 1 (2009): 106-112. https://www.jstor.org/stable/40214576.

${ }^{3}$ Alan Sangster, "You Cannot Judge a Book by Its Cover: The Problems with Journal Rankings," Accounting Education: An International Journal 24, no. 3 (2015): 175-86. http://dx.doi.org/10.1080/09639284.2015.1055929.

${ }^{4}$ Mark Tadajewski, "Academic Labour, Journal Ranking Lists and the Politics of Knowledge Production in Marketing," Journal of Marketing Management 32, no. 1-2 (2016): 1-18. https://doi.org/10.1080/0267257X.2015.1120508.

${ }_{5}^{5}$ Peggy Johnson, Fundamentals of Collection Development and Management, 2nd edition (Chicago: ALA Editions, 2005) 418.

${ }^{6}$ Thomas E. Nisonger, "Journals in the Core Collection," The Serials Librairan 51, no. 3-4 (2007): 51-73. https://doi.org/10.1300/J123v51n03 05.

${ }^{7}$ Chad Albrecht, Jeffrey A. Thompson, Jeffrey L. Hoopes, and Pablo Rodrigo, "Business Ethics Journal Rankings as Perceived by Business Ethics Scholars," Journal of Business Ethics 95, no. 2 (2010): 227-237. https://www.jstor.org/stable/40785084.

${ }^{8}$ Russell R. Currie and Gurupdesh S. Pandher, "Finance Journal Rankings: Active Scholar Assessment Revisited," Journal of Banking and Finance 111, (2020): Article 105717. https://doi.org/10.1016/j.jbankfin.2019.105717.

${ }^{9}$ Marlene Walk and Fredrik O. Andersson, "Where do Nonprofit and Civil Society Researchers Publish? Perceptions of Nonprofit Journal Quality," Journal of Public and Nonprofit Affairs 6, no. 1 (2020): 79-96. https://doi.org/10.20899/jpna.6.1.79-96.

${ }^{10}$ Bruce Thyer, "A Note from the Editor: A Comprehensive List of Social Work Journals," Research on Social Work Practice 14, no. 4 (2005): 310-11. https://doi.org/10.1177/1049731505276381.

${ }^{11}$ David A. Fabianic, "Perceived Scholarship and Readership of Criminal Justice Journals," Journal of Police Science and Administration 8, no. 1 (1980): 15-20.

https://www.ojp.gov/ncjrs/virtual-library/abstracts/perceived-scholarship-and-readershipcriminal-justice-journals

${ }^{12}$ David Fabianic, "Institutional Affiliation of Authors in Selected Criminal Justice Journals," Journal of Criminal Justice 9, no. 3 (1981): 247-52. https://doi.org/10.1016/00472352(79)90004-7.

${ }^{13}$ Jack R. Greene, Timothy S. Bynum, and Vincent J. Webb, "Paradigm Development in CrimeRelated Education: The Role of the Significant Others," Criminal Justice Review 10, no. 2 (1985): 7-17. https://doi.org/10.1177/073401688501000202.

${ }^{14}$ Jon Sorensen, Clete Snell, and John J. Rodriguez, "An Assessment of Criminal Justice and Criminology Journal Prestige," Journal of Criminal Justice Education 17, no. 2 (2006): 297-321. https://doi.org/10.1080/10511250500336203.

${ }^{15}$ Frank P. Williams III, Marilyn D. McShane, Carl P. Wagoner, "Differences in Assessments of Relative Prestige and Utility of Criminal Justice and Criminology Journals," American Journal of Criminal Justice 19, no. 2 (1995): 215-38. https://doi.org/10.1007/BF02885916. 
${ }^{16}$ William H. Walters, "Key Questions in the Development and Use of Survey-Based Journal Rankings," The Journal of Academic Librarianship 43, (2017): 305-11. https://doi.org/10.1016/j.acalib.2017.05.002.

${ }^{17}$ R.A. Weisheit and R.M. Regoli, "Ranking Journals," Scholarly Publishing 14, no. 4 (1985): 313-25.

${ }^{18}$ Alexander Serenko and Nick Bontis, “A Critical Evaluation of Expert Survey-Based Journal Rankings: The Role of Personal Research Interests," ASIS\&T 69, no. 5 (2018): 749-752. https://doi.org/10.1002/asi.23985.

${ }^{19}$ William H. Walters, "Key Questions in the Development and Use of Survey-Based Journal Rankings," The Journal of Academic Librarianship 43, (2017): 305-11. https://doi.org/10.1016/j.acalib.2017.05.002.

${ }^{20}$ G.S. Bobrinski, "An Analysis of 105 Major U.S. Journals in Library and Information Science.” In Library Science Annual, Volume 1, edited by B.S. Wynar and H. Cameron, 29-41, Littleton CO: Libraries Unlimited.

${ }^{21}$ Robin A. Paynter, Rose M. Jackson, and Laura Bowering Mullen, "Core Journal Lists: Classic Tool, New Relevance,” Behavioral \& Social Sciences Librarian 29, no. 1 (2010): 279-89. https://doi.org/10.1080/01639260903571096.

${ }^{22}$ Bluma C. Peritz, "The Methods of Library Science Research: Some Results from a Bibliometric Survey," Library Research 2, no. 3 (1980): 251-268. https://eric.ed.gov/?id=EJ240921.

${ }^{23}$ Judith Serebnick and Stephen P. Harter, "Ethical Practices in Journal Publishing: A Study of Library and Information Science Periodicals," Library Quarterly 60, no. 2 (1990): 91-119. https://www.jstor.org/stable/4308451.

${ }^{24}$ Mary Jane Brustman and Barbara E. Kemp, "Finding Criminology and Criminal Justice Journal Literature: A Comparison and Analysis of Selected Indexing and Abstracting Services," Journal of Criminal Justice Education 11, no. 2 (2000): 371-82. https://doi.org/10.1080/10511250000084991.

${ }^{25}$ Serebnick and Harter, "Ethical Practices in Journal Publishing: A Study of Library and Information Science Periodicals," 100.

${ }^{26}$ Paynter, Jackson, and Mullen, "Core Journal Lists: Classic Tool, New Relevance," 17.

27 Thomas E. Nisonger, The '80/20 Rule' and Core Journals," The Serials Librarian 55, no. 1-2 (2008): 62-84. https://doi.org/10.1080/03615260801970774.

${ }^{28}$ Michael C. Hall, "Publish and Perish? Bibliometric Analysis, Journal Ranking, and the Assessment of Research Quality in Tourism," Tourism Management 32, (2011): 16-27. 2010 https://doi.org/10.1016/j.tourman.2010.07.001.

${ }^{29}$ Thomas E. Nisonger, "Journals in the Core Collection: Definition, Identification, and Applications," The Serials Librarian 51, no. 3-4 (2007): 51-73. https://doi.org/10.1300/J123v51n03 05.

${ }^{30}$ Kailash Chandra Garg, Suresh Kumar, and Rahul Kumar Singh, "Bibliometric Study of the Coverage and Overlap of Journals Indexed by Four Abstracting and Indexing Services in Library and Information Science," The Serials Librarian 79, no. 1-2 (2020): 118-130. https://doi.org/10.1080/0361526X.2019.1704341.

${ }_{31}$ P.L.K. Gross and E.M. Gross, "College Libraries and Chemical Engineering," Science 66, no. 1713 (1927): 385-389. https://www.jstor.org/stable/1651803.

${ }^{32}$ Nisonger, "Journals in the Core Collection," 57. 
${ }^{33}$ Ellen G. Cohn and David P. Farrington, "Scholarly Influence in Criminology and Criminal Justice Journals in 1990-2005," Criminal Justice Review 37, no. 3 (2012): 360-83. https://doi.org/10.1177/0734016812450025.

${ }^{34}$ Eileen M. Ahlin, "Broadening the Productivity Lens in Criminology and Criminal Justice: An Exploratory Study of the Research Contributions of Master's Degree Program Faculty, 20142018," Journal of Criminal Justice Education 31, no. 1 (2020): 100-23. https://doi.org/10.1080/10511253.2019.1668033.

35 Ibid.

${ }^{36}$ Jonathan R. Sorensen, "Scholarly Productivity in Criminal Justice: Institutional Affiliation of Authors in Top Ten Criminal Justice Journals," Journal of Criminal Justice 22, no. 6 (1994): 535-47. https://doi.org/10.1016/0047-2352(94)90094-9.

${ }^{37}$ Pan Su, Changjing Shang, Tianhua Chen, and Qiang Shen, "Exploiting Data Reliability and Fuzzy Clustering for Journal Ranking," IEEE Transactions on Fuzzy Systems 25, no. 5 (2017): 1306-19. https://doi.org/10.1109/TFUZZ.2016.2612265.

${ }^{38}$ Ibid., 387.

${ }^{39}$ Steve Black, "Practical Applications of Do-It-Yourself Citation Analysis," The Serials Librarian 64, no. 1-4 (2013): 285-98. https://doi.org/10.1080/0361526X.2013.760420.

${ }^{40}$ Dennis W. Fell, Judy F. Burnham, Melanie J. Buchanan, Heidi A. Horchen, and Joel A. Scherr, "Mapping the Core Journals of the Physical Therapy Literature," Journal of the Medical Library Associatiion: JMLA 99, no. 3 (2011): 202-7. https://doi.org/10.3163/15365050.99.3.007.

${ }^{41}$ Jagannathan Ramakrishnan, Govindan Ravi Sanka, and Kotti Thavamani, "Primary Journals in the Field of Pediatric Dentistry (2000-2019)," Library Philosophy and Practice (e-journal), Article 4289. https://digitalcommons.unl.edu/libphilprac/4289/.

42 Eileen Wakiji, "Mapping the Literature of Physical Therapy," Bulletin of the Medical Library Association 85, no. 3 (1997): 284-8. https://www.ncbi.nlm.nih.gov/pmc/articles/PMC226272/.

${ }^{43}$ Web of Science, "The Clarivate Analytics Impact Factor," https://clarivate.com/webofsciencegroup/essays/impact-factor/ (accessed April 2, 2021).

${ }^{44}$ Scopus, "Access and Use Support Center: Four-Year Window," https://service.elsevier.com/app/answers/detail/a_id/14880/supporthub/scopus/ (accessed April 7, 2021).

${ }^{45}$ Web of Science Group, "Journal Citation Reports: Journal Impact Factor (JIF)," https://clarivate.libguides.com/ld.php?content id=55911188 (accessed April 7, 2021).

${ }^{46}$ Scopus, "CiteScore 2019 Now LIVE!,” https://blog.scopus.com/posts/citescore-2019-now-live (accessed April 7, 2021).

${ }^{47}$ Web of Science Group, "Master List," https://mjl.clarivate.com/search-results (accessed April 2, 2021).

${ }^{48}$ Scopus, "Sources," https://www.scopus.com/sources, (accessed April 7, 2021).

49 Scopus, "CiteScore 2019 Now LIVE!"

${ }^{50}$ Cassidy R. Sugimoto and Vincent Larivière. Measuring research: what everyone needs to know. Oxford University Press, 2018.

${ }^{51}$ Marie-Hélène Magri and Aline Solari, "The SCI Journal Citation Reports: A Potential Tool for Studying Journals?," Scientometrics 35, no. 1 (1996): 93-117. https://doi.org/10.1007/BF02018235. 
${ }^{52}$ Web of Science, "Journal Citation Reports,"

https://clarivate.com/webofsciencegroup/solutions/journal-citation-reports/ (accessed April 2, 2021).

${ }^{53}$ Kathrine Corby, "Constructing Core Journal Lists: Mixing Science and Alchemy,” Portal: Libraries and the Academy 3, no. 2 (2003): 207-17. https://doi.org/10.1353/pla.2003.0029.

54 Thomas E. Nisonger, "Use of the Journal Citation Reports for Serials Management in Research Libraries: An Investigation of the Effect of Self-Citation on Journal Rankings in Library and Information Science and Genetics," College \& Research Libraries 61, no. 3 (2000): 263-75. https://doi.org/10.5860/crl.61.3.263.

${ }^{55} \mathrm{Su}$, Shang, Chen, and Shen, "Exploiting Data Reliability and Fuzzy Clustering for Journal Ranking," 1306.

${ }^{56}$ Bertrand Malsch and Sophie Tessier, "Journal Ranking Effects on Junior Academics: Identity Fragmentation and Politicization," Critical Perspectives on Accounting 26, (2015): 84-98. https://doi.org/10.1016/j.cpa.2014.02.006.

${ }_{57}$ Joyita Chakraborty, Dinesh K. Pradhan, and Subrata Nandi, "On the Identification and Analysis of Citation Pattern Irregularities Among Journals," Expert Systems, Article e12561 (2020): 1-17. doi: https://doi.org/10.1111/exsy.12561.

${ }^{58}$ Cassidy R. Sugimoto and Vincent Larivière. Measuring research: what everyone needs to know. Oxford University Press, 2018.

59 Javad Hayatdavoudi and Mansour Haghighat, "How Hot are Hot Papers? The Issue of Prolificacy and Self-Citation Stacking," Scientometrics 26, no. 1 (2021): 565-78. https://doi.org/10.1007/s11192-020-03749-2.

${ }^{60}$ Petr Heneberg, "From Excessive Journal Self-Cites to Citation Stacking: Analysis of Journal Self-Citation Kinetics in Search for Journals, Which Boost Their Scientometric Indicators," PLoS One 11, no. 4 (2016): 1-20. https://doi.org/10.1371/journal.pone.0153730.

${ }^{61}$ Gordana Budimir, Sophia Rahimeh, Sameh Tamimi,Primož Južni, "Comparison of Self-Citation Patterns in WoS and Scopus Databases Based on National Scientifc Production in Slovenia (1996-2020)," Scientometrics 126, no. 3 (2021): 2249-67. https://doi.org/10.1007/s11192-021-03862-w.

${ }^{62}$ Christina DeJong and Sarah St. George, "Measuring Journal Prestige in Criminal Justice and Criminology," Journal of Criminal Justice Education 29, no. 2 (2018): 290-309. https://doi.org/10.1080/10511253.2017.1398344.

${ }^{63}$ George Lăzăroiu, "On Citation Ethics: Editorial Shenanigans to Boost Impact Factor," Contemporary Readings in Law \& Social Justice 5, no. 1 (2013): 82-87.

https://link.gale.com/apps/doc/A344602980/AONE?u=anon e 5c3d539\&sid=bookmarkAONE\&xid=bc398ab1.

${ }^{64}$ William H. Walters, "Citation-Based Journal Rankings: Key Questions, Metrics, and Data Sources," IEEE Access 5 (2017): 22036-53. https://doi.org/10.1109/ACCESS.2017.2761400.

${ }^{65}$ Hilary I. Okagbue, Sheila A. Bishop, Pelumi E. Oguntunde, Patience I. Adamu, Abiodun A. Opanuga, Elvir M. Akhmetshin, "Modified CiteScore Metric for Reducing the Effect of SelfCitations," Telkomnika 17, no. 6 (2019): 3044-49. https://doi.org/10.12928/TELKOMNIKA.v17i6.12292.

${ }^{66}$ Web of Science, "View of Journal Citation Reports Suppression Policy," https://clarivate.com/webofsciencegroup/wp-content/uploads/sites/2/2020/06/jcr-suppressionpolicy-2020.pdf (accessed April 2, 2021). 
${ }^{67}$ Joseph Aubele and Carol Perruso, "Toward a Sustainable Method for Core Journal Lists: A Test Case Using Journals in Social Work," The Serials Librarian 73, no. 2 (2017): 89-106. https://doi.org/10.1080/0361526X.2017.1342113.

${ }^{68}$ Joseph W. Aubele, "Educational Psychology at the Core: Adapting a Sustainable Method for Core Journal Lists," Collection Management 46, no. 2 (2021): 125-141.

https://doi.org/10.1080/01462679.2020.1795773.

${ }^{69}$ Ebsco, "Law \& Criminal Justice: Featured Databases," https://www.ebsco.com/academiclibraries/subjects/law-criminal-justice\#: $\sim$ :text $=$ Criminal $\% 20 \mathrm{Justice} \% 20 \mathrm{Abstracts} \% 20 \mathrm{is} \% 20$ the,policing\%2C\%20criminal\%20law\%20and\%20investigation. (accessed April 8, 2021).

${ }^{70}$ Proquest, "Criminal Justice Database," https://about.proquest.com/productsservices/pq criminal justice.html (accessed April 8, 2021).

${ }^{71}$ Web of Science Group, "About Citable Items," https://help.incites.clarivate.com/incitesLiveJCR/9607-TRS (accessed April 8, 2021).

${ }^{72}$ Web of Science Group, "Clarivate Analytics Impact Factor," https://clarivate.com/webofsciencegroup/essays/impact-factor/ (accessed April 8, 2021).

${ }^{73}$ Scopus, "CiteScore 2019 Now LIVE!"

${ }^{74}$ Scopus, "What is the Complete List of Scopus Subject Areas and All Science Journal Classification Codes (ASJC)?" https://service.elsevier.com/app/answers/detail/a id/15181/c/10547/supporthub/scopus/related/1/ session/L2F2LzEvdGltZS8xNjE3OTA0MTA2L2dlbi8xNjE3OTA0MTA2L3NpZC9mVXFUajh sYTJTWTFuRGZHcU1TTFJHUHRCN2hjOEJHWk9Ibkxsd0xKTmlfV2cxUSU3RXc0eU9Fcm h1ZFVaZ2VzTVFNV1dxc3I0bXFMQkRkS00wbm0wYjZhUUpHelhWemFSNjVhT1pDa1E1S2 ZhWTISJTdFUFNEYmk1aVp3JTIxJTIx/ (accessed April 8, 2021).

${ }^{75}$ Chaim Zins and Plácida L.V.A.C. Santos, "Mapping the Knowledge Covered by Library Classification Systems, ” Journal of the American Society for Information Science and Technology 62, no. 5 (2011): 877-901. https://doi.org/10.1002/asi.21481.

76 Tina Gross, Arlene G. Taylor, and Daniel N. Joudrey "Still a Lot to Lose: The Role of Controlled Vocabulary in Keyword Searching. Cataloging \& Classification Quarterly 53, no. 1 (2015): 1-39. https://doi.org/10.1080/01639374.2014.917447.

${ }^{77}$ Amitabha Chatterjee, Elements of Information Organization and Dissemination (Cambridge, MA: Chandros, 2017).

${ }^{78}$ Library of Congress, "Introduction to the Library of Congress Subject Headings."

Library of Congress Subject Headings. Library of Congress.

https://www.loc.gov/aba/publications/FreeLCSH/LCSH42\%20Main\%20intro.pdf (accessed August 5, 2020).

79 DeJong and St. George, "Measuring Journal Prestige in Criminal Justice and Criminology," 302.

${ }^{80}$ Ibid., 296.

${ }^{81}$ Ibid., 298.

82 Ibid., 300.

${ }^{83}$ Ibid., 298.

${ }^{84}$ Ibid., 302.

${ }^{85}$ Brenda I. Rowe, Wesley S. McCann, and Craig Hemmens, "Persona Non Grata: The Marginalization of Legal Scholarship in Criminology and Criminal Justice Journals," Journal of 
Criminal Justice Education 28, no. 4 (2017): 514-41.

https://doi.org/10.1080/10511253.2016.1267242.

This is an electronic version of an article published as Joseph Aubele \& Gabriel J. Gardner (2021) Criminal Justice and Criminology at the Core: Using a Sustainable Method for Constructing a Core Journal List, The Serials Librarian AHEAD OF PRINT, 1 - 16, doi: 10.1080/0361526X.2021.1986195. Serials Librarian is available online at: $\underline{\text { https://www.tandfonline.com/loi/wser20 }}$ 